\title{
Use of dried brewers' grains instead of soybean meal to feed lactating cows
}

\section{Andressa Faccenda ${ }^{1 *}$, Maximiliane Alavarse Zambom ${ }^{1}$, Deise Dalazen Castagnara ${ }^{2}$, André Sanches de Avila ${ }^{1}$, Tatiane Fernandes ${ }^{3}$, Everline Inês Eckstein ${ }^{1}$, Fernando Andre Anschau ${ }^{1}$, Cibele Regina Schneider ${ }^{1}$}

\author{
${ }^{1}$ Universidade Estadual do Oeste do Paraná, Programa de Pós-graduação em Zootecnia, Marechal Cândido Rondon, PR, Brazil. \\ 2 Universidade Federal do Pampa, Uruguaiana, RS, Brazil. \\ ${ }^{3}$ Universidade Federal de Lavras, Programa de Pós-graduação em Zootecnia, Lavras, MG, Brazil.
}

\begin{abstract}
The objective of this study was to determine the optimal level of dried brewers' grains (DBG) to replace soybean meal in diets for lactating Holstein cows. Five cows, around $88 \pm 28$ days in milk, were distributed in a $5 \times 5$ Latin square design and fed diets containing different levels of $\operatorname{DBG}(0,25,50,75$, and 100\%). The forage:concentrate ratio of the diet was 50:50. Feed intake, dry matter, nutrient digestibility, microbial synthesis, milk production and composition, and the economic viability of the diets were evaluated. There was reduction in dry matter intake and, consequently, in crude protein and non-fiber carbohydrates with increased levels of DBG. This occurred due to physical limitation of rumen caused by increased neutral detergent fiber intake. Ether extract intake also increased with levels of DBG due to higher concentrations of this nutrient in the diet. Apparent dry matter, organic matter, ether extract, and neutral detergent fiber digestibility increased with replacement of soybean meal by DBG. Milk production showed a quadratic effect and the levels of fat, protein, and total solids reduced linearly. Each $1 \%$ of soybean meal replaced by DBG in concentrate led to a reduction of $0.04,0.02$, and $0.06 \mathrm{~g} \mathrm{~kg}^{-1}$ of milk fat, protein, and total solids, respectively. The milk production efficiency increased linearly and the microbial synthesis efficiency was not affected. The economic return increased along with the DBG levels. Thus, DBG levels replacing up to $75 \%$ of soybean meal can be used to feed lactating cows, since it provides improvements in digestibility, milk production efficiency, and economic return without affecting microbial efficiency.
\end{abstract}

Key Words: by-product, digestibility, intake, milk composition, protein, purine

\section{Introduction}

In Brazil, the most commonly used ingredient as protein source in animal feed is soybean meal. However, the majority of soybeans are exported, mainly for the European market (Coronel et al., 2009), which has raised the grain and soybean meal cost in the domestic market. This scenario has motivated the search for alternative feed ingredients that can be stored, cost less, and have a comparable nutritional composition.

The use of agribusiness waste for ruminant feed provides a reduction in feed cost and allows for the reuse of organic material in animal production, thus preventing

Received: May 25, 2016

Accepted: October 19, 2016

*Corresponding author: andressafaccenda@hotmail.com

http://dx.doi.org/10.1590/S1806-92902017000100007

How to cite: Faccenda, A.; Zambom, M. A.; Castagnara, D. D.; Avila, A. S.; Fernandes, T.; Eckstein, E. I.; Anschau, F. A. and Schneider, C. R. 2017. Use of dried brewers' grains instead of soybean meal to feed lactating cows. Revista Brasileira de Zootecnia 46(1):39-46.

Copyright $\odot 2017$ Sociedade Brasileira de Zootecnia. This is an Open Access article distributed under the terms of the Creative Commons Attribution License (http://creativecommons.org/licenses/by/4.0/), which permits unrestricted use, distribution, and reproduction in any medium, provided the original work is properly cited. waste accumulation and environmental pollution (Brochier and Carvalho, 2009). Among the various industrial wastes, brewers' grains has increased due the excessive supply used for increased beer production in Brazil (Albuquerque et al., 2011). The amount of wet brewers' grains is $32.02 \%$ higher than the amount of barley used for the initial process of brewing beer (Brochier and Carvalho, 2009).

High humidity of waste might limit its utilization on farms distant from the brewing industry, because the humidity prevents transportation and storage. Thus, the drying process is an interesting alternative, which also increases the lifespan of brewer's grains and reduces the storage volume (Aliyu and Bala, 2011). However, data using dried brewers' grains (DBG) in lactating cow diets are scarce. The use of brewer waste in the wet and fermented forms for lactating cows have showed positive results, because it does not affect the dry matter intake (Chiou et al., 1998) and milk production (West et al., 1994; Firkins et al., 2002; Geron et al, 2010; Imaizumi et al., 2015), but causes an increase in fat contents (Davis et al., 1983) and milk protein (West et al., 1994).

With a protein content ranging between $190 \mathrm{~g} \mathrm{~kg}^{-1}$ and $308.0 \mathrm{~g} \mathrm{~kg}^{-1}$ of dry matter (DM) (Russ et al., 2005; Valadares 
Filho et al., 2006), DBG is an alternative protein ingredient of lower cost, which can be used instead of soybean meal in ruminant feed, as ruminants have the capacity to convert plant waste into nutrients through the action of rumen microorganisms (Silva Filho et al., 1999). In this context, the objective of this study was to determine the optimal level of DBG for replacement of soybean meal in diets for lactating Holstein cows.

\section{Material and Methods}

The experimental protocol was approved by the Ethic Committee on Animal Use (case no. 35/13) and performed following the ethical principles of animal experimentation. Five pregnant Holstein cows between the first and third lactation were used, with $88+28$ days in milk, an average body weight of $626 \pm 31.9 \mathrm{~kg}$ (mean \pm standard deviation), and an average initial milk yield of $27.0 \pm 4.86 \mathrm{~kg} \mathrm{~d}^{-1}$. The animals were assigned to a $5 \times 5$ Latin square design of 21 days, with 14 days for adaptation and seven days for data collection, totaling 105 days. The treatments were 0,25 , 50,75 , and $100 \%$ of DBG levels replacing soybean meal in the diets.

Brewer's grains were acquired in the wet form from a brewery located at Toledo, Paraná, Brazil. The wet waste was passed through a 31-h dehydration process. Sixteen hours involving direct sun exposure, in which the waste was distributed on a concrete surface forming a layer of approximately $1.5 \mathrm{~cm}$ with a density of $0.998 \mathrm{~kg}$ of DM per $\mathrm{m}^{2}$. The material was spread and turned over every hour. At the end of the dehydration process, the DBG was collected, packed in bags, and stored in a covered barn.

The ingredients used in the formulation of experimental diets were Cynodon sp. hay, corn silage, ground corn, DBG, soybean meal, and a mineral and inorganic phosphate supplement. Diets were formulated to be isonitrogenous, according to the NRC (2001) for dairy cows with a body weight of $626 \mathrm{~kg}$ that are producing $27 \mathrm{~kg}$ of milk per day. The forage:concentrate ratio was 50:50 (Table 1).

Animals were housed in individual stalls in a barn. At the beginning and end of each experimental period, the cows were weighed before the morning feeding. The feed was offered twice daily at $06.30 \mathrm{~h}$ and $04.30 \mathrm{~h}$, with $700 \mathrm{~g} \mathrm{~kg}^{-1}$ and $300 \mathrm{~g} \mathrm{~kg}^{-1}$ of feed provided at each time, respectively. The refusals were weighed daily and adjusted for $100 \mathrm{~g} \mathrm{~kg}^{-1}$ of DM offered. Dry matter and nutrient intake were determined by the difference between the offered and refused feed.

From the 15th to 21 st day of the study period, diet samples were collected, including silage, hay, concentrate, and refusals, and stored at $-20{ }^{\circ} \mathrm{C}$. To determine the digestibility, fecal samples were collected directly from the rectum according to the following schedule: 15th day $(08.00 \mathrm{~h}), 16$ th day $(10.00 \mathrm{~h}), 17$ th day $(12.00 \mathrm{~h}), 18$ th day $(14.00 \mathrm{~h}), 19$ th day $(16.00 \mathrm{~h})$ and 20 th day $(18.00 \mathrm{~h})$. Subsequently, samples of diets, refusals and feces were dried in a forced-ventilation oven $\left(55^{\circ} \mathrm{C}\right.$ for $\left.72 \mathrm{~h}\right)$ and ground to pass through a 1-mm mill screen. The pool of samples was collected to compose a representative sample of diets, refusals, and feces per animal per period.


diets

\begin{tabular}{|c|c|c|c|c|c|}
\hline \multirow{2}{*}{ Ingredient } & \multicolumn{5}{|c|}{ Replacement level (\%) } \\
\hline & 0 & 25 & 50 & 75 & 100 \\
\hline Tifton 85 hay & 400.00 & 400.00 & 400.00 & 400.00 & 400.00 \\
\hline Corn silage & 100.00 & 100.00 & 100.00 & 100.00 & 100.00 \\
\hline Ground corn & 382.74 & 360.72 & 332.09 & 280.52 & 176.47 \\
\hline Soybean meal & 104.23 & 94.24 & 78.14 & 53.82 & - \\
\hline Dried brewers' grains & - & 32.50 & 78.14 & 154.94 & 313.73 \\
\hline Mineral supplement ${ }^{1}$ & 9.77 & 9.75 & 9.77 & 9.79 & 9.80 \\
\hline Dicalcium phosphate & 3.26 & 2.79 & 1.86 & 0.93 & - \\
\hline \multicolumn{6}{|l|}{ Nutritional composition } \\
\hline Dry matter $\left(\mathrm{g} \mathrm{kg}^{-1}\right.$ as fed $)$ & 817.27 & 818.67 & 820.65 & 822.58 & 828.36 \\
\hline Organic matter & 941.80 & 940.72 & 940.97 & 940.69 & 939.19 \\
\hline Ether extract & 20.32 & 23.43 & 26.17 & 26.92 & 36.32 \\
\hline Crude protein & 145.12 & 143.42 & 145.08 & 145.07 & 148.33 \\
\hline Neutral detergent fiber & 405.07 & 434.60 & 463.20 & 512.58 & 605.20 \\
\hline Acid detergent fiber & 203.25 & 208.87 & 218.46 & 227.11 & 258.26 \\
\hline Non-fibrous carbohydrates & 411.44 & 385.70 & 358.50 & 318.24 & 228.01 \\
\hline Metabolizable energy & 2.68 & 2.66 & 2.62 & 2.56 & 2.43 \\
\hline
\end{tabular}

${ }^{1}$ Chemical composition (quantities in kg-1): Ca, 215 g; P, 65 g; Co, 45 mg; Mg, 12 g; Mn, 425 mg; Zn, 1900 mg; Se, 35 mg; I, 65 mg; S, 10 g; F, 650 mg; Fe, 1700 mg; Cu, 800 mg; $\mathrm{Na}, 75 \mathrm{~g}$ (commercial product). 
Samples were analyzed for DM, mineral matter (MM), crude protein (CP), and ether extract (EE) by AOAC (1990) methodology and neutral detergent fiber (NDF) and acid detergent fiber (ADF) quantification according to Van Soest et al. (1991). The amount of organic matter (OM) was calculated as the difference between the MM content and total DM. Non-fiber carbohydrate levels (NFC) were calculated according to equations proposed by Sniffen et al. (1992). Dietary metabolizable energy was calculated according to the equation from the NRC (2001).

The DM and nutrient digestibilities were estimated by the difference between the amount consumed and amount excreted. To estimate the daily fecal excretion, insoluble acid detergent fiber (iADF) was used as an internal marker. The iADF was estimated in samples of offered feed, refusals, and feces by an in situ digestibility procedure. The iADF was obtained after $264 \mathrm{~h}$ of incubation (Casali et al., 2008 ) in $\mathrm{F} 57$ filters (ANKOM ${ }^{\circledR}$ Technology Corporation) and then analyzed for ADF.

Cows were milked twice daily at 06:00 and 04:00 h. Milk production was recorded during the collection period using gauges attached to the milking equipment. The fat corrected milk (FCM) for $35 \mathrm{~g} \mathrm{~kg}^{-1}$ of fat was calculated according to Sklan et al. (1992). Milk production efficiency (MPE) was calculated by dividing the milk yield average of each cow by its DM intake average in each experimental period.

Milk samples were collected on the 15th and 16th day of each period and were composed proportionally from the morning and afternoon milking. For chemical analysis, milk samples were placed in plastic vials containing Bronopol ${ }^{\mathbb{R}}$ (2-bromo-2-nitropopano-1,3-diol), which were mailed to the laboratory to determine the contents of fat, protein, lactose, and total solids.

To measure milk allantoin and urea nitrogen, milk samples were deproteinized on filter paper using $5 \mathrm{~mL}$ of $25 \%$ trichloroacetic acid to $10 \mathrm{~mL}$ of milk. Subsequently, the filtrate was used to determine allantoin by the same method used in determination of urine allantoin according to Chen and Gomes (1992). Milk urea nitrogen was measured using a commercial kit.

For evaluation of microbial synthesis, urine was collected on the 17th day as spot sampling $4 \mathrm{~h}$ after the morning feeding. Uric acid and creatinine concentrations were determined by the colorimetric method. The average daily excretion of creatinine, considered to indicate the urinary volume, was $24.05 \mathrm{mg} \mathrm{kg}^{-1}$ body weight (Chizzotti et al., 2007). Total purine excretion was estimated by the sum of allantoin excreted in urine and milk plus uric acid excreted in the urine. Absorbed microbial purines $\left(\mathrm{mmol} \mathrm{d}^{-1}\right)$ were estimated by the equation proposed by Verbic et al. (1990). The intestinal flow of microbial nitrogen $\left(\mathrm{g} \mathrm{d}^{-1}\right)$ was estimated from the equation by Chen and Gomes (1992).

To determine the economic viability of DBG, we considered the amount paid to the farmer for a liter of milk (US\$ 0.43 per L) and prices related to the ration ingredients practiced in Paraná in November, 2014: corn silage, US\$ 0.11 per $\mathrm{kg}$ of DM; Tifton hay, US\$ 0.17 per $\mathrm{kg}$ of DM; ground corn, US\$ $0.21 \mathrm{~kg}$ per of DM; soybean meal, US\$ 0.50 per kg of DM; DBG, US\$ 0.17 per $\mathrm{kg}$ of DM; mineral supplement, US\$ 1.02 per $\mathrm{kg}$ of DM; and inorganic phosphate, US\$ 0.84 per $\mathrm{kg}$ of DM. The value of US\$ 1.00 in the economic analysis period was equivalent to $\mathrm{R} \$ 2.557$. The economic approach only considered the feed cost due to research purposes.

The ration cost per kilogram was calculated from the chemical composition of each ingredient in the diet and its cost. The feed cost was obtained by multiplying the ration cost by the animal's average intake of each treatment diet. Similarly, the gross revenue obtained for each treatment was calculated with the milk liter value and the milk production. The gross margin was calculated as the difference between gross revenue and feed cost. The equilibrium point was calculated by the ration cost divided by the milk liter value. The equilibrium point shows the exact production volume when there is zero return, i.e., when the gross revenue is equal to the feed cost.

The data were analyzed as a $5 \times 5$ Latin square design using the MIXED procedure of SAS (Statistical Analysis System, version 9.2.). The mathematical model used was:

$$
\gamma_{\mathrm{ijk}}=\mu+\tau_{\mathrm{i}}+\mathrm{p}_{\mathrm{j}}+\mathrm{c}_{\mathrm{k}}+\varepsilon_{\mathrm{ijk}},
$$

in which $\gamma_{\mathrm{ijk}}=$ observation, $\mu=$ population mean, $\tau_{\mathrm{i}}=$ diet effect ( $\mathrm{i}=1$ to 5 ), $\mathrm{p}_{\mathrm{j}}=$ period effect $\left(\mathrm{j}=1\right.$ to 5 ), $\mathrm{c}_{\mathrm{k}}=$ cow effect $(\mathrm{k}=1$ to 5$)$, and $\varepsilon_{\mathrm{ijk}}=$ residual error. Various covariance structures of errors were fitted. The first-order autoregressive structure (AR(1)) was selected based on the lowest Bayesian information criterion. The effects of DBG levels were evaluated by orthogonal polynomials testing linear and quadratic effects. Significance was declared at $\mathrm{P} \leq 0.05$.

\section{Results}

The use of DBG instead of soybean meal had a linear effect, decreasing the body weight, DM, OM, CP, and NFC intake in $\mathrm{kg} \mathrm{d}^{-1}(\mathrm{P}<0.05)$ (Table 2). Dry matter intake $\mathrm{g} \mathrm{kg}^{-1} \mathrm{~d}^{-1}$ and $\mathrm{g} \mathrm{kg}^{-0.75} \mathrm{~d}^{-1}$ had a quadratic effect $(\mathrm{P}<0.05)$. The maximum intake was estimated using the replacement levels of $22.5 \%$ and $18.4 \%$ of DBG, respectively. Ether extract intake in $\mathrm{kg} \mathrm{d}^{-1}$, NDF intake in $\mathrm{kg} \mathrm{d}^{-1}, \mathrm{~g} \mathrm{~kg}^{-1} \mathrm{~d}^{-1}$ 
and $\mathrm{g} \mathrm{kg}^{-0.75} \mathrm{~d}^{-1}$ showed a positive linear effect with the increase of $\mathrm{DBG}$ in the diet $(\mathrm{P}<0.05)$. The ADF intake and metabolizable energy did not show any effect by the replacement levels $(\mathrm{P}>0.05)$.

Apparent DM and OM digestibilities were linearly increased $(\mathrm{P}<0.05)$ with DBG levels (Table 3$)$. A positive linear effect was also obtained for EE and NDF digestibilities with an increasing level of DBG in the concentrate $(\mathrm{P}<0.05)$. The CP digestibility showed a quadratic effect with minimal digestibility estimated when there was $11.2 \%$ of DBG in the concentrate replacing soybean meal $(\mathrm{P}<0.05)$. The ADF and NFC digestibility was not affected $(\mathrm{P}>0.05)$ by the treatments (Table 3).

Milk production and fat corrected milk showed quadratic effect $(\mathrm{P}<0.05) \quad$ (Table 4). Milk production efficiency increased linearly $(\mathrm{P}<0.05)$. Milk fat, protein, and total solids expressed in $\mathrm{g} \mathrm{kg}^{-1}$ showed a decreasing linear effect $(\mathrm{P}<0.05)$. Milk fat, lactose, and total solids in $\mathrm{kg} \mathrm{d}^{-1}$ showed a quadratic effect $(\mathrm{P}<0.05)$ with the production peak estimated at $23.7 \%, 23.7 \%$, and $31.5 \%$ of

Table 2 - Body weight, daily dry matter, and nutrient intake of Holstein cows fed diets containing different levels of dried brewers' grains replacing soybean meal

\begin{tabular}{|c|c|c|c|c|c|c|c|c|}
\hline \multirow{2}{*}{ Variable } & \multicolumn{5}{|c|}{ Replacement level (\%) } & \multicolumn{2}{|c|}{ P-value } & \multirow{2}{*}{ SEM } \\
\hline & 0 & 25 & 50 & 75 & 100 & Linear & Quadratic & \\
\hline $\mathrm{BW}(\mathrm{kg})^{1}$ & 623.40 & 623.60 & 614.40 & 621.80 & 599.40 & 0.002 & 0.110 & 5.91 \\
\hline DMI $\left(\mathrm{kg} \mathrm{d}^{-1}\right)^{2}$ & 19.68 & 19.37 & 18.49 & 18.30 & 15.28 & $<0.001$ & 0.016 & 0.75 \\
\hline DMI $\left(\mathrm{g} \mathrm{kg}^{-1} \mathrm{~d}^{-1}\right)^{3}$ & 31.76 & 31.37 & 30.39 & 29.64 & 24.21 & $<0.001$ & 0.007 & 1.17 \\
\hline DMI $\left(\mathrm{g} \mathrm{kg}^{-0.75} \mathrm{~d}^{-1}\right)^{4}$ & 158.41 & 156.34 & 150.91 & 147.70 & 121.32 & $<0.001$ & 0.008 & 5.84 \\
\hline OMI $\left(\mathrm{kg} \mathrm{d}^{-1}\right)^{5}$ & 18.57 & 18.25 & 17.42 & 17.26 & 14.40 & $<0.001$ & 0.014 & 0.70 \\
\hline $\operatorname{EEI}\left(\mathrm{kg} \mathrm{d}^{-1}\right)^{6}$ & 0.41 & 0.47 & 0.51 & 0.50 & 0.60 & $<0.001$ & 0.806 & 0.03 \\
\hline $\mathrm{CPI}\left(\mathrm{kg} \mathrm{d}^{-1}\right)^{7}$ & 2.88 & 2.81 & 2.72 & 2.68 & 2.29 & $<0.001$ & 0.101 & 0.13 \\
\hline NDFI $\left(\mathrm{kg} \mathrm{d}^{-1}\right)^{8}$ & 7.61 & 7.92 & 8.76 & 9.08 & 9.04 & 0.009 & 0.571 & 0.62 \\
\hline $\operatorname{NDFI}\left(\mathrm{g} \mathrm{kg}^{-1} \mathrm{~d}^{-1}\right)^{9}$ & 12.27 & 12.82 & 14.38 & 14.69 & 14.33 & 0.013 & 0.304 & 0.98 \\
\hline NDFI $\left(\mathrm{g} \mathrm{kg}^{-0.75} \mathrm{~d}^{-1}\right)^{10}$ & 61.22 & 63.90 & 71.43 & 73.27 & 71.79 & 0.012 & 0.359 & 4.90 \\
\hline $\operatorname{ADFI}\left(\mathrm{kg} \mathrm{d}^{-1}\right)^{11}$ & 3.79 & 3.79 & 3.81 & 3.97 & 3.77 & 0.695 & 0.749 & 0.19 \\
\hline $\operatorname{NFCI}\left(\mathrm{kg} \mathrm{d}^{-1}\right)^{12}$ & 8.50 & 7.90 & 6.99 & 6.10 & 3.69 & $<0.001$ & $<0.001$ & 0.30 \\
\hline $\operatorname{MEI}\left(\mathrm{Mcal} \mathrm{d}^{-1}\right)^{13}$ & 39.26 & 40.60 & 41.93 & 41.02 & 37.16 & 0.471 & 0.066 & 2.38 \\
\hline
\end{tabular}

BW - body weight; DMI - dry matter intake; OMI - organic matter intake; EEI - ether extract intake; CPI - crude protein intake; NDFI - neutral detergent fiber intake; ADFI - acid detergent fiber intake; NFCI - non-fibrous carbohydrate intake; MEI - metabolizable energy intake; SEM - standard error of the mean.

${ }^{1} \hat{Y}=626.4800-0.1992 x$

${ }^{2} \hat{Y}=20.1971-0.0395 x$.

${ }^{3} \hat{Y}=31.4326+0.0453 x-0.0011 x^{2}$.

${ }^{4} \hat{Y}=156.8702+0.1989 x-0.0054 x^{2}$.

${ }^{5} \hat{\mathrm{Y}}=19.0440-0.0373 \mathrm{x}$.

${ }^{6} \hat{\mathrm{Y}}=0.4169+0.0016 \mathrm{x}$.

${ }^{7} \hat{\mathrm{Y}}=2.9404-0.0053 \mathrm{x}$.

${ }^{8} \hat{\mathrm{Y}}=7.6760+0.0161 \mathrm{x}$.

${ }^{9} \hat{\mathrm{Y}}=12.5044+0.0239 \mathrm{x}$.

${ }^{10} \hat{\mathrm{Y}}=62.2232+0.1220 \mathrm{x}$.

${ }^{11} \hat{\mathrm{Y}}=3.826$.

${ }^{12} \hat{\mathrm{Y}}=8.9202-0.0456 \mathrm{x}$.

${ }^{13} \hat{Y}=39.994$

Table 3 - Apparent dry matter and nutrient digestibility ( $\mathrm{g} \mathrm{kg}^{-1}$ of dry matter) of Holstein cow diets containing different levels of dried brewers' grains replacing soybean meal

\begin{tabular}{|c|c|c|c|c|c|c|c|c|}
\hline \multirow{2}{*}{ Variable } & \multicolumn{5}{|c|}{ Replacement level (\%) } & \multicolumn{2}{|c|}{ P-value } & \multirow{2}{*}{ SEM } \\
\hline & 0 & 25 & 50 & 75 & 100 & Linear & Quadratic & \\
\hline $\mathrm{DMD}^{1}$ & 630.75 & 643.85 & 636.26 & 652.80 & 667.79 & 0.049 & 0.563 & 17.02 \\
\hline $\mathrm{OMD}^{2}$ & 654.06 & 665.88 & 658.83 & 675.98 & 691.33 & 0.036 & 0.468 & 15.98 \\
\hline $\mathrm{EED}^{3}$ & 551.73 & 630.02 & 684.78 & 662.35 & 786.02 & $<0.001$ & 0.824 & 22.50 \\
\hline $\mathrm{CPD}^{4}$ & 597.74 & 617.65 & 617.95 & 649.64 & 713.08 & $<0.001$ & 0.026 & 17.51 \\
\hline $\mathrm{NDFD}^{5}$ & 538.98 & 573.38 & 596.23 & 622.96 & 663.41 & $<0.001$ & 0.646 & 18.04 \\
\hline $\mathrm{ADFD}^{6}$ & 478.09 & 510.62 & 476.94 & 471.50 & 514.56 & 0.656 & 0.593 & 35.15 \\
\hline $\mathrm{NFCD}^{7}$ & 762.69 & 764.66 & 765.65 & 760.03 & 748.91 & 0.521 & 0.431 & 20.08 \\
\hline
\end{tabular}

DMD - dry matter digestibility; OMD - organic matter digestibility; EED - ether extract digestibility; CPD - crude protein digestibility; NDFD - neutral detergent fiber digestibility; ADFD - acid detergent fiber digestibility; NFCD - non-fibrous carbohydrate digestibility; SEM - standard error of the mean.

${ }^{1} \hat{\mathrm{Y}}=629.6845+0.3321 \mathrm{x}$.

$2 \hat{Y}=652.2879+0.3386 x$

${ }^{3} \hat{\mathrm{Y}}=562.7931+2.0037 \mathrm{x}$

${ }^{4} \hat{Y}=603.5974-0.3029 x+0.0135 x^{2}$

${ }^{5} \hat{Y}=539.3026+1.1936 x$.

${ }^{6} \hat{\mathrm{Y}}=490.342$.

${ }^{7} \hat{Y}=760.388$. 
DBG, respectively. Milk urea nitrogen concentrations were not affected by DBG levels $(\mathrm{P}>0.05)$.

Allantoin and urine uric acid showed linear and quadratic effects $(\mathrm{P}<0.05)$ respectively, with the increase of DBG in the concentrate, while milk allantoin $(\mathrm{P}<0.05)$ showed no effect (Table 5). As a result of the decline in urine allantoin concentrations, total purines also showed a linear decrease $(\mathrm{P}<0.05)$. Microbial purines absorbed in $\mathrm{mmol} \mathrm{d}^{-1}$, N-microbial production, and microbial $\mathrm{CP}$ expressed in $\mathrm{g} \mathrm{d}^{-1}$ showed a linear effect with different DBG levels in the concentrate $(\mathrm{P}<0.05)$. However, efficiency of microbial protein synthesis ( $\mathrm{g}$ of $\mathrm{CP}-\mathrm{mic}^{\mathrm{kg}} \mathrm{kg}^{-1} \mathrm{~d}^{-1}$ of total digestible nutrients) did not differ $(\mathrm{P}<0.05)$ between the different DBG levels (Table 5).

Table 4 - Milk production, composition, and urea nitrogen of Holstein cows fed diets containing different levels of dried brewers' grains replacing soybean meal

\begin{tabular}{|c|c|c|c|c|c|c|c|c|}
\hline \multirow{2}{*}{ Variable } & \multicolumn{5}{|c|}{ Replacement level (\%) } & \multicolumn{2}{|c|}{ P-value } & \multirow{2}{*}{ SEM } \\
\hline & 0 & 25 & 50 & 75 & 100 & Linear & Quadratic & \\
\hline Milk production $\left(\mathrm{kg} \mathrm{d}^{-1}\right)^{1}$ & 24.40 & 24.25 & 25.00 & 24.40 & 22.40 & 0.0206 & 0.047 & 0.96 \\
\hline $3.5 \%$ Fat corrected milk $\left(\mathrm{kg} \mathrm{d}^{-1}\right)^{2}$ & 25.31 & 25.34 & 25.21 & 24.64 & 20.92 & $<0.001$ & 0.004 & 0.83 \\
\hline Milk production efficiency ${ }^{3}$ & 1.26 & 1.29 & 1.36 & 1.34 & 1.47 & 0.007 & 0.746 & 0.05 \\
\hline Fat $\left(\mathrm{g} \mathrm{kg}^{-1}\right)^{4}$ & 36.97 & 36.04 & 35.46 & 36.01 & 31.52 & 0.002 & 0.072 & 1.08 \\
\hline Fat $\left(\mathrm{kg} \mathrm{d}^{-1}\right)^{5}$ & 0.91 & 0.90 & 0.88 & 0.87 & 0.70 & $<0.001$ & 0.001 & 0.03 \\
\hline Protein $\left(\mathrm{g} \mathrm{kg}^{-1}\right)^{6}$ & 31.92 & 31.54 & 30.52 & 31.13 & 29.52 & 0.006 & 0.713 & 0.65 \\
\hline Protein $\left(\mathrm{kg} \mathrm{d}^{-1}\right)^{7}$ & 0.78 & 0.79 & 0.77 & 0.75 & 0.65 & 0.005 & 0.107 & 0.04 \\
\hline Lactose $\left(\mathrm{g} \mathrm{kg}^{-1}\right)^{8}$ & 44.80 & 45.23 & 45.41 & 45.43 & 45.34 & 0.364 & 0.341 & 0.32 \\
\hline Lactose $\left(\mathrm{kg} \mathrm{d}^{-1}\right)^{9}$ & 1.10 & 1.13 & 1.15 & 1.10 & 1.01 & 0.022 & 0.038 & 0.04 \\
\hline Total solids $\left(\mathrm{g} \mathrm{kg}^{-1}\right)^{10}$ & 123.58 & 122.71 & 121.25 & 122.34 & 116.14 & $<0.001$ & 0.065 & 1.33 \\
\hline Total solids $\left(\mathrm{kg} \mathrm{d}^{-1}\right)^{11}$ & 3.03 & 3.07 & 3.05 & 2.96 & 2.58 & 0.002 & 0.016 & 0.12 \\
\hline Milk urea nitrogen $\left(\mathrm{mg} \mathrm{dL}^{-1}\right)^{12}$ & 13.31 & 13.30 & 13.66 & 14.67 & 14.31 & 0.205 & 0.844 & 1.14 \\
\hline
\end{tabular}

SEM - standard error of the mean.

${ }^{1} \hat{Y}=24.3314+0.0479 x-0.0007 x^{2}$.

${ }^{2} \hat{Y}=25.0453+0.0528 x-0.0009 x^{2}$

${ }^{3} \hat{\mathrm{Y}}=1.2484+0.0019 \mathrm{x}$

${ }^{4} \hat{\mathrm{Y}}=37.3860-0.0437 \mathrm{x}$.

${ }^{5} \hat{\mathrm{Y}}=0.8926+0.0019 \mathrm{x}-0.00004 \mathrm{x}^{2}$.

${ }^{6} \hat{\mathrm{Y}}=31.9680-0.0208 \mathrm{x}$.

${ }^{7} \hat{Y}=0.8096-0.0012 x$.

${ }^{8} \hat{\mathrm{Y}}=45.242$.

${ }^{9} \hat{\mathrm{Y}}=1.0940+0.0019 \mathrm{x}-0.00004 \mathrm{x}^{2}$.

${ }^{10} \hat{\mathrm{Y}}=124.2540-0.0610 \mathrm{x}$

${ }^{11} \hat{\mathrm{Y}}=3.0091+0.0063 \mathrm{x}-0.0001 \mathrm{x}^{2}$.

$12 \hat{\mathrm{Y}}=13.820$.

Table 5 - Purine derivative excretions and microbial synthesis of lactating Holstein cows fed diets containing different levels of dried brewers' grains replacing soybean meal

\begin{tabular}{|c|c|c|c|c|c|c|c|c|}
\hline \multirow{2}{*}{ Variable } & \multicolumn{5}{|c|}{ Replacement level (\%) } & \multicolumn{2}{|c|}{ P-value } & \multirow{2}{*}{ SEM } \\
\hline & 0 & 25 & 50 & 75 & 100 & Linear & Quadratic & \\
\hline \multicolumn{9}{|c|}{ Purine derivative excretions $\left(\mathrm{mmol} \mathrm{d}^{-1}\right)$} \\
\hline Urine allantoin ${ }^{1}$ & 315.99 & 306.51 & 304.02 & 298.83 & 264.96 & 0.024 & 0.324 & 17.18 \\
\hline Milk allantoin ${ }^{2}$ & 31.49 & 37.29 & 27.75 & 34.93 & 28.99 & 0.743 & 0.433 & 5.30 \\
\hline Uric acid $^{3}$ & 32.01 & 32.75 & 31.00 & 25.94 & 19.87 & 0.004 & 0.004 & 2.49 \\
\hline Total purine ${ }^{4}$ & 379.50 & 376.55 & 362.77 & 359.70 & 313.82 & 0.033 & 0.150 & 20.03 \\
\hline \multicolumn{9}{|c|}{ Microbial purines $\left(\mathrm{mmol} \mathrm{d}^{-1}\right)$} \\
\hline Absorbed purines ${ }^{5}$ & 389.97 & 386.48 & 370.91 & 366.79 & 314.35 & 0.038 & 0.163 & 23.77 \\
\hline \multicolumn{9}{|c|}{ Microbial production $\left(\mathrm{g} \mathrm{d}^{-1}\right)$} \\
\hline Microbial $\mathrm{N}^{6}$ & 283.53 & 280.99 & 269.67 & 266.68 & 228.55 & 0.038 & 0.163 & 17.28 \\
\hline Microbial $\mathrm{CP}^{7}$ & 1772.06 & 1756.19 & 1685.41 & 1666.72 & 1428.42 & 0.038 & 0.163 & 108.02 \\
\hline Microbial $\mathrm{CP} \mathrm{kg}^{-1} \mathrm{TDN}^{8}$ & 163.44 & 156.90 & 152.59 & 151.60 & 144.78 & 0.070 & 0.833 & 10.49 \\
\hline
\end{tabular}

CP - crude protein; TDN - total digestible nutrients; SEM - standard error of the mean.

${ }^{1} \hat{\mathrm{Y}}=320.0112-0.4389 \mathrm{x}$.

${ }^{2} \hat{\mathrm{Y}}=32.090$.

${ }^{3} \hat{Y}=32.1171+0.0691 x-0.0019 x^{2}$.

${ }^{4} \hat{\mathrm{Y}}=388.1098-0.5928 \mathrm{x}$.

${ }^{5} \hat{\mathrm{Y}}=399.8893-0.6838 \mathrm{x}$.

${ }^{6} \hat{\mathrm{Y}}=290.7376-0.4971 \mathrm{x}$.

${ }^{7} \hat{\mathrm{Y}}=1817.1116-3.1070 \mathrm{x}$.

${ }^{8} \hat{\mathrm{Y}}=153.862$. 
The economic viability (Table 6) shows the gross margin of greater value and the lowest equilibrium point that occurred to treatment of $100 \%$ DBG.

\section{Discussion}

Body weight decreased with the increase in the level of DBG because the diets with DBG had lower energy density. Animals fed diets with higher levels of DBG showed reduction in dry matter intake and mobilized body reserves to maintain their milk production. Animals fed diets containing $100 \%$ DBG consumed $4.4 \mathrm{~kg}$ DM per day less than the control treatment (Table 2). Using DBG above these levels may have limited the DM intake due to its high NDF (663 $\mathrm{g} \mathrm{kg}^{-1} \mathrm{DM}$ ), which led to intake regulation by physical filling. Davis et al. (1983) also observed that DM intake was reduced when 30 or $40 \%$ of DM from wet brewers' grain was used in the feed.

Ether extract and NDF intake increased along with DBG level in the diet (Table 1). Geron et al. (2010) also showed an increase in EE intake $\left(\mathrm{g} \mathrm{kg}^{-0.75} \mathrm{~d}^{-1}\right)$ of around $8 \%$ when lactating cows were fed $15 \%$ brewer's grain silage compared with cows fed a diet with $0 \%$ brewers' grain silage. Mertens (1992) suggested that NDF intake of an animal up to $12 \mathrm{~g} \mathrm{~kg}^{-1} \mathrm{~d}^{-1}$ of body weight is the main mechanism of physical regulation of DM intake. Thus the NDF intake observed for the treatments with $50 \%, 75 \%$, and $100 \%$ DBG was $14.4,14.7$, and $14.3 \mathrm{~g} \mathrm{~kg}^{-1} \mathrm{~d}^{-1}$ of body weight, respectively, confirming the fact that high levels of DBG in the concentrate limited feed intake.

Organic matter, $\mathrm{CP}$, and NFC intake decreased as a result of a reduction in DM intake. In the case of NFC, this reduction also occurred due to the low NFC concentration in diets with greater amounts of DBG.

Apparent DM and OM digestibility increased with DBG levels (Table 3), which may be related to an increased feed retention time in the rumen due to higher NDF in diets with DBG. Doreau et al. (2003) reported that the main cause of digestibility variation in the diet is the retention time of particles in the rumen (i.e., a lower DM intake leads to a reduction in passage rate and a consequent increase in its apparent digestibility). The increase in EE and NDF digestibility can be attributed to a slower passage rate and a greater concentration of these nutrients in the diets with higher DBG levels. The greater digestibility of NDF can also be associated with an improved ruminal condition, since the use of fibrous byproducts increases rumen motility and maintains a higher $\mathrm{pH}$, which favors the fibrolytic microorganisms.

The CP digestibility was high because, although the brewers' grains present low ruminal degradability, high intestinal digestibility (Santos et al., 1984) leads to a high total apparent digestibility. This was also reported by Geron et al. (2007), who found larger amounts of rumen undegradable protein but degradable in the small intestine with fermented beer residue $\left(394 \mathrm{~g} \mathrm{~kg}^{-1} \mathrm{CP}\right)$ compared with soybean meal $\left(187 \mathrm{~g} \mathrm{~kg}^{-1} \mathrm{CP}\right)$.

Milk production and fat corrected milk showed quadratic effect with maximum production estimated at $34.2 \%$ and $29.3 \%$ of DBG replacing soybean meal, respectively. This corroborates with the results of Imaizumi et al. (2015), who demonstrated higher fat corrected milk with $20 \%$ of wet brewers' grains in the diet DM. This estimated maximum production may have occurred due to better nutrient synchronization and the presence of essential amino acids for milk synthesis such as lysine and methionine. According to the NRC (2001), DBG contains $10.4 \mathrm{~g}$ of lysine per $100 \mathrm{~g}$ of $\mathrm{CP}$ and $4.3 \mathrm{~g}$ of methionine per $100 \mathrm{~g}$ of $\mathrm{CP}$, while soybean meal has $13.9 \mathrm{~g}$ of lysine per $100 \mathrm{~g}$ of $\mathrm{CP}$ and $3.2 \mathrm{~g}$ of methionine per $100 \mathrm{~g}$ of $\mathrm{CP}$.

Milk production efficiency increased along with a reduction in DM intake with increased levels of DBG. However, it should be noted that this increase in milk production efficiency disregards the reduction in body weight observed in cows consuming larger amounts of DBG, which, in the long term, may adversely affect production and reproduction. Davis et al. (1983) also assessed feed efficiency and obtained an apparent increase in this ratio due to body weight loss along with increasing wet brewers' grain levels in the diet.

Table 6 - Economic analysis of the use of increasing levels of dried brewers' grains to replace the soybean meal concentrate in the diet of lactating Holstein cows

\begin{tabular}{|c|c|c|c|c|c|}
\hline \multirow{2}{*}{ Variable } & \multicolumn{5}{|c|}{ Replacement level (\%) } \\
\hline & 0 & 25 & 50 & 75 & 100 \\
\hline Ration cost (US\$ $\mathrm{kg}^{-1}$ dry matter) & 0.22 & 0.22 & 0.21 & 0.20 & 0.18 \\
\hline Feed cost $\left(\mathrm{US} \$ \mathrm{~d}^{-1}\right)$ & 4.39 & 4.24 & 3.92 & 3.69 & 2.75 \\
\hline Gross revenue (US\$ d ${ }^{-1}$ ) & 10.50 & 10.43 & 10.75 & 10.50 & 9.64 \\
\hline Gross margin (US\$ d $\left.{ }^{-1}\right)$ & 6.10 & 6.19 & 6.83 & 6.81 & 6.89 \\
\hline Equilibrium point $\left(\mathrm{kg}\right.$ of milk d $\left.{ }^{-1}\right)$ & 10.61 & 9.85 & 9.11 & 8.58 & 6.39 \\
\hline
\end{tabular}


The reduction in milk fat may have occurred as a result of the reduction in DM intake and also because DBG is a rich source of polyunsaturated fatty acids (Geron et al., 2007), which can promote milk fat depression. For protein, each $1 \%$ of soybean meal replaced by DBG in the concentrate lead to a reduction of $20.8 \mathrm{mg} \mathrm{kg}^{-1}$ and $1.2 \mathrm{~g} \mathrm{~d}^{-1}$ of milk protein. This differed from West et al. (1994) and Cozzi and Polan (1994), who found an increase in the milk protein content of cows fed brewers' grains in both wet and dry forms.

Concentrations of milk urea nitrogen were not affected, although DBG and soybean meal showed some differences regarding their protein use by animals. After ruminal incubation for $16 \mathrm{~h}$, Geron et al. (2007) noted values of rumen degradable protein of $436 \mathrm{~g} \mathrm{~kg}^{-1}$ of DM for wet brewers' grains and $797 \mathrm{~g} \mathrm{~kg}^{-1}$ of DM for soybean meal, while the rumen undegradable protein was $564 \mathrm{~g} \mathrm{~kg}^{-1}$ CP for wet brewers' grains and $204 \mathrm{~g} \mathrm{~kg}^{-1} \mathrm{CP}$ for soybean meal. As the diets in the present study were isoproteic, these factors were not enough to characterize differences in urea nitrogen concentrations. Additionally, the milk urea nitrogen values obtained are near the range between 10 and $14 \mathrm{mg} \mathrm{dL}^{-1}$, which was described by Powell et al. (2011) as the ideal, since it demonstrates adequate synchronization between proteins and carbohydrates in the diet.

$\mathrm{N}$-microbial production and microbial $\mathrm{CP}$ in $\mathrm{g} \mathrm{d}^{-1}$ decreased with increasing DBG levels. Santos and Pedroso (2011) emphasized that the reduction in microbial production may be related to lower carbohydrate availability and lower dietary protein degradability for protein synthesis. This can explain the results of the current study because, according to Santos et al. (1984), brewers' grains generate a smaller contribution of ammonia $\mathrm{N}$ due to lower ruminal degradable CP present in this feed. Additionally, diets with higher DBG levels also had lower corn proportions (Table 1), which reduced the availability of rapidly fermenting carbohydrates, limiting microbial growth and protein synthesis. However, microbial efficiency was not affected by treatments regardless of the difference in rumen degradable protein content of diets (628.5 $\mathrm{g}$ of rumen degradable protein $\mathrm{kg}^{-1}$ of CP for diet containing $0 \%$ DBG and $575.8 \mathrm{~g}$ of rumen degradable protein $\mathrm{kg}^{-1}$ of $\mathrm{CP}$ for diet containing $100 \% \mathrm{DBG}$ ). This effect may be due to the lower DM intake and consequently higher retention time in the rumen of diets with higher DBG, which probably allowed a more efficient protein degradation of this diet (Table 5). Microbial efficiency for all levels of DBG was greater than the $130 \mathrm{~g} \mathrm{~kg}^{-1}$ of total digestible nutrients recommended by the NRC (2001).

The economic viability showed that the total replacement of soybean meal by $\mathrm{DBG}$ reduces the cost in US\$ by $\$ 0.04$ per $\mathrm{kg}$ of dietary DM, due to the $64.6 \%$ lower cost of this waste comparted with the soybean meal (Table 6). The average daily cost of feed also decreased with increasing DBG levels due to the reduction in the cost per $\mathrm{kg}$ of dietary DM and to the decline in DM intake.

The gross margin of greater value and the lowest equilibrium point occurred with $100 \%$ DBG replacement, making this the most advantageous diet over the short term. However, treatment with $75 \%$ DBG showed a gross margin similar to treatment with $100 \%$ DBG, the latter causing a marked reduction in DM intake as well as reduced body weight of the animals.

\section{Conclusions}

Dried brewers' grains can be used instead of soybean meal in dairy cow feed as it provides improvements in digestibility, milk production efficiency, and economic return to the producer without affecting microbial efficiency. However, due to the decrease in dry matter intake, body weight, milk production, milk fat, and milk protein, the use of DBG is not recommended to replace more than $75 \%$ of soybean meal.

\section{Acknowledgments}

The authors would like to thank the Coordenação de Aperfeiçoamento de Pessoal de Nível Superior (CAPES grant - PNPD 2891/2010) for their financial support.

\section{References}

Albuquerque, D. M. N.; Lopes, J. B.; Klein Junior, M. H.; Merval, R. R.; Silva, F. E. S. and Teixeira, M. P. F. 2011. Resíduo desidratado de cervejaria para suínos em terminação. Arquivo Brasileiro de Medicina Veterinária e Zootecnia 63:465-472.

Aliyu, S. and Bala, M. 2011. Brewer's spent grain: A review of its potentials andapplications. African Journal of Biotechnology 10:324-331.

AOAC - Association of Official Analytical Chemists. 1990. Official methods of analysis. 16th ed. AOAC Internacional, Arlington.

Brochier, M.A. and Carvalho, S. 2009. Aspectos ambientais, produtivos e econômicos do aproveitamento de resíduo úmido de cervejaria na alimentação de cordeiros em sistema de confinamento. Ciência e Agrotecnologia 3:1392-1399.

Casali, A. O.; Detmann, E.; Valadares Filho, S. C.; Pereira, J. C.; Henriques, L. T.; Freitas, S. G. and Paulino, M. F. 2008. Influência do tempo de incubação e do tamanho de partículas sobre os teores de compostos indigestíveis em alimentos e fezes bovinas obtidos por procedimentos in situ. Revista Brasileira de Zootecnia $37: 335-342$

Chen, X. B. and Gomes, M. J. 1992. Estimation of microbial protein supply to sheep and cattle based on urinary excretion of purine derivatives - an overview of technical details. Rowett Research Institute/International Feed Research Unit, Bucksburnd. p.21. 
Chiou, P. W. S.; Chen, C. R.; Chen, K. J. and Yu, B. 1998. Wet brewers' grains or bean curd pomance as partial replacement of soybean meal for lactating cows. Animal Feed Science and Technology 74:123-134.

Chizzotti, M. L.; Valadares Filho, S. C.; Valadares, R. F. D.; Chizzotti, F. H. M.; Marcondes, M. I. and Fonseca, M. A. 2007. Consumo, digestibilidade e excreção de uréia e derivados de purinas em vacas de diferentes níveis de produção de leite. Revista Brasileira de Zootecnia 36:138-146.

Coronel, D. A.; Machado, J. A. D. and Carvalho, F. M. A. 2009. Análise da competitividade das exportações do complexo soja brasileiro de 1995 a 2006: Uma abordagem de market-share. Revista de Economia Contemporânea 13:281-307.

Cozzi, G. and Polan, C. E. 1994. Corn gluten meal or dried brewers grains as partial replacement for soybean meal in the diet of Holstein cows. Journal of Dairy Science 77:825-834.

Davis, C. L.; Grenawalt, D. A. and McCoy, G. C. 1983. Feeding values of pressed brewers' grains for lactating dairy cows. Journal of Dairy Science 66:73-79.

Doreau, M.; Michalet-Doreau, B.; Grimaud, P.; Atti, N. and Nozière, P. 2003. Consequences of underfeeding on digestion and absorption in sheep. Small Ruminant Research 49:289-301.

Firkins, J. L.; Harvatine, D. I.; Sylvester, J. T. and Eastridge, M. L. 2002. Lactation performance by dairy cows fed wet brewers grain or whole cottonseed to replace forage. Journal of Dairy Science $85: 2662-2668$.

Geron, L. J. V.; Zeoula, L. M.; Branco, A. F.; Erke, J. A.; Prado, O. P. P. and Jacobi, G. 2007. Caracterização, fracionamento protéico, degradabilidade ruminal e digestibilidade in vitro da matéria seca e proteína bruta do resíduo de cervejaria úmido e fermentado. Acta Scientiarum. Animal Science 29:291-299.

Geron, L. J. V.; Zeoula, L. M.; Erkel, J. A.; Prado, I. N.; Bublitz, E. and Prado, O. P. P. 2010. Consumo, digestibilidade dos nutrientes, produção e composição do leite de vacas alimentadas com resíduo de cervejaria fermentado. Acta Scientiarum. Animal Science 32:69-76.

Imaizumi, H.; Batistel, F.; Souza, J and Santos, F. A. P. 2015. Replacing soybean meal for wet brewer's grains or urea on the performance of lactating dairy cows. Tropical Animal Health Production 47:877-882.

Mertens, D. R. 1992. Analysis of fiber and its uses in feed evaluation and ration formulation. p.1-32. In: Anais do $29^{\circ}$ Simpósio
Internacional de Ruminantes, Reunião Anual da Sociedade Brasileira de Zootecnia, Lavras.

NRC - National Research Council. 2001. Nutrient requirements of dairy cattle. 7th ed. National Academy Press, Washington, D.C.

Powell, J. M.; Wattiaux, M. A. and Broderick, G. A. 2011. Short communication: Evaluation of milk urea nitrogen as a management tool to reduce ammonia emissions from dairy farms. Journal of Dairy Science 94:4690-4694.

Russ, W.; Mörtel, H. and Meyer-Pittroff, R. 2005. Application of spent grains to increase porosity in bricks. Construction and Building Materials 19:117-126.

Santos, K. A.; Stern, M. D. and Satter, L. D. 1984. Protein degradation in the rumen and amino acid absorption in the small intestine of lactation dairy cattle fed various protein sources. Journal of Animal Science 51:244-255.

Santos, F. A. P. and Pedroso, A. M. 2011. Metabolismo de proteínas. p.265-297. In: Nutrição de ruminantes. 2nd ed. Berchielli, T. T.; Pires, A. V. and Oliveira, S. G., eds. Funep, Jaboticabal.

Silva Filho, J. C.; Armelin, M. J. A. and Silva, A. G. 1999. Determinação da composição mineral de subprodutos agroindustriais utilizados na alimentação animal pela técnica de ativação neutrônica. Pesquisa Agropecuária Brasileira 34:235-241.

Sklan, D.; Ashkenazi, R.; Braun, A.; Devorin, A. and Tabori, K. 1992. Fatty acids, calcium soaps of fatty acids, and cottonseeds fed to high yielding cows. Journal of Dairy Science 75:2463-2472.

Sniffen, C. J.; O'Connor, J. D.; Van-Soest, P. J.; Fox, D. G. and Russell, J. B. 1992. A net carbohydrate and protein system for evaluating cattle diets: II. Carbohydrate and protein availability. Journal of Animal Science 70:3562-3577.

Valadares Filho, S. C.; Magalhães, K. A.; Rocha Júnior, V. R. and Capelle, E. R. 2006. Tabelas brasileiras de composição de alimentos para bovinos: CQBAL 2.0. 2.ed. UFV, Viçosa, MG.

Van Soest, P. J.; Robertson, J. B. and Lewis, B. A. 1991. Carbohydrate methodology, metabolism, and nutritional implications in dairy cattle. Journal of Dairy Science 74:3583-3597.

Verbic, J.; Chen, X. B.; MacLeod, N. A. and Orskov, E. R. 1990 Excretion of purine derivatives by ruminants. Effect of microbial nucleic acid infusion on purine derivative excretion by steers. Journal of Agricultural Science 114:243-248.

West, J. W.; Ely, L. O. and Martin, S. A. 1994. Wet brewers grain for lactating dairy cows during hot, humid weather. Journal of Dairy Science 77:196-204. 